\title{
„BEZ CÍRKVE MIZÍ KRISTUS V MINULOSTI, BEZ KRISTA SE STÁVÁ CÍRKEV POUHOU ORGANIZACÍ.“ VZTAH KRISTA A CÍRKVE V DÍLE JOSEPHA RATZINGERA - BENEDIKTA XVI.
}

PAVEL FRÝVALDS KÝ

$\mathrm{T}$ éma vztahu Krista a církve zůstává stále aktuální. Naše země patří k těm oblastem, kde se k církvi přistupuje spíše s nedůvěrou a kde je velkým pokušením i těch, kteří se považují za křestany, žít svou víru soukromně a necírkevně. Podobný trend můžeme spatřovat nejen u nás, ale i v mnoha dalších západních zemích. Při povrchním pohledu se zdá, že současný člověk má problematický vztah především k církvi, nikoliv k víře jako takové, a to ve smyslu hesla: „Ježíš ano, církev ne.“ Po první světové válce došlo v mnoha evropských zemích k oživení vztahu k církvi (u nás to však úplně neplatí), takže Romano Guardini na katolické straně mluvil o tom, že „se církev probouzí v duších“, a Otto Dibelius na protestantské straně dokonce nové století označil za „století církve“. Po Druhé světové válce je patrná spíše „církevní krize“. ${ }^{1}$ Můžeme říci, že Druhý vatikánský koncil, který navazuje na církevní hnutí ve snaze obnovit pohled na církev, dějinně spadá do počátku této krize.

Skutečnost problematické identifikace dnešního člověka s církví má jistě vícero příčin, at' už historických, sociologických nebo psychologických. Ve své nejhlubší podstatě se však jedná o otázku teologickou, totiž o otázku, jaký je vzájemný vztah mezi Kristem a církví. Proto je toto téma výzvou především pro systematické teology. Jedním z teologů, který významným způsobem přispěl k překonání duality

1 Srov. RATZINGER, Joseph. Vom Ursprung und vom Wesen der Kirche. In RATZINGER, Joseph. Gesammelte Schriften. Kirche - Zeichen unter den Völkern. Schriften zur Ekklesiologie und Ökumene. Müller, Gerhard Ludwig (ed.). Sv. 8/1, (JRGS 8/1). Freiburg i. Br.: Herder, 2010, s. 141. 
Kristus - církev, je bezesporu Joseph Ratzinger, současný papež Benedikt XVI.

Peter Seewald, německý novinář a autor tří knih rozhovorů s Josephem Ratzingerem, ve své knize Benedikt XVI. - portrét zblizka zachytil svědectví Eugena Bisera, významného mnichovského fundamentálního teologa, který nepatří k Ratzingerovým obdivovatelům:

Nakonec zůstane vzpomínka na teologa (Ratzingera), který uskutečnil to, co se dnes už takměř nedá očekávat, a sice znovuobjevení církve. Zůstane vzpomínka na teologa, který $\mathrm{v}$ předpokoji této doby bojoval holýma rukama za překonání církevní krize. Především tím, že představil církev jako fenomén Božího lidu a umožnil tak oživit církevní strukturu ve smyslu dialogického principu, jak to vyžadoval Druhý vatikánský koncil, který (Ratzinger) prosazoval. (...) Proč se mu to podařilo? (...) Protože konsekventně vztahoval fenomén církve a křestanství na osobu Krista. ${ }^{2}$

Toto hodnocení Eugena Bisera je pro nás cenné, nebot' vystihuje jeden ze základních rysů Ratzingerovy teologie: objevovat církev úzce zakotvenou v tajemství Ježíše Krista. Důležitým Ratzingerovým předchůdcem v tomto přístupu byl, kromě jiných, především Romano Guardini, který podstatu křestanství spatřoval v osobě Ježíše Krista, ${ }^{3}$ a v jehož díle lze podobně jako u Ratzingera sledovat myšlenkový pohyb od ekleziologie k christologii, nebo spíše od liturgie k christologii. ${ }^{4}$ Tento vývoj však můžeme zařadit do širšího teologického proudu, na který upozorňuje Walter Kasper. Podle tohoto německého teologa

2 SEEWLAD, Peter. Benedikt XVI. Portrét zblizka. Trnava: Spolok Svätého Vojtecha, 2007, s. 119.

3 „Die Person Jesu Christi in ihrer geschichtlichen Einmaligkeit und ewigen Herrlichkeit ist selbst die Kategorie, welche Sein, Tun und Lehre des Christlichen bestimmt.“ GUARDINI, Romano. Das Wesen des Christentums. 3. vydání. Würzburg: Werkbund Verlag, 1953, s. 81.

4 Srov. RATZINGER, Joseph. Von der Liturgie zur Christologie. Romano Guardinis theologischer Grundansatz und seine Aussagekraft. In RATZINGER, Joseph (ed.). Wege zur Wahrheit. Die bleibende Bedeutung von Romano Guardini. Düsseldorf: Patmos Verlag, 1985, s. 121-144. K vlivu Guardiniho na Ratzingera v době studií srov. RATZINGER, Joseph. Můj život. Vzpomínky na cestu ke kněžství a biskupskému úŕadu. 2. vydání. Brno: Barrister \& Principal, 2005, s. 43. LÄPPLE, Alfred. Benedikt XVI. und seine Wurzeln. Was sein Leben und seinen Glauben prägte. Augsburg: Sankt Ulrich Verlag, 2006, s. 48. O podnětné souvislosti mezi myšlením Guardiniho a Ratzingera s ohledem na téma christologie a ekleziologie (liturgie) srov. HEIBEL, Franz-Xaver. Theologische Denker als Mitarbeiter der Wahrheit - Romano Guardini und Papst Benedikt XVI. In VODERHOLZER, Rudolf - SCHALER, Christian - HEIBL, Franz-Xaver (ed.). Mitteilungen des-Institut Papst-Benedikt XVI. Regensburg: Verlag Schnell \& Steiner, 2008, s. 59-73. 
dominantní zájem o ekleziologii v padesátých a šedesátých letech 20. století vystřídal od počátku let sedmdesátých intenzivnější zájem o christologii. Nebot́ má-li se objevit pravá podstata církve a její působení ve světě, je nejprve potřeba vyjádřit její vztah k Ježíši Kristu, jako ke svému „základu a smyslu“.5

Pokud se má Ježíš ukázat jako „základ a smysl“ církve, je třeba objevit skutečného Krista, tedy ne Krista, který je projekcí našich tužeb, naší osobní filosofie nebo dokonce ideologie. Je možné takového Krista nalézt? Ratzingerova odpověd' jde ve směru, který vytyčil již zmiňovaný Guardini. Pro Guardiniho je tím prostorem, který chrání Ježíše před námi samotnými, před našimi vlastními zájmy a projekcemi, církev. ${ }^{6}$

Poznáváme tak úzkou vazbu mezi Kristem a církví, jak ji reflektuje Ratzinger s Guardinim: Bez Krista je církev mrtvá, a bez církve je Kristus nepoznatelný. Ovšem proč tomu tak je a jaké to má důsledky pro ekleziologii a christologii? Na to se pokusíme dát odpověd' na základě analýzy díla Josepha Ratzingera. Ačkoliv ve světové teologii probíhá poměrně rozsáhlá debata o Ratzingerově teologii, ${ }^{7} \mathrm{v}$ českém prostředí se našemu tématu nikdo hlouběji nevěnoval. Cílem tohoto př́spěvku přiblížit českému čtenáři jednu z důležitých oblastí teologie současného papeže s vědomím, že nebudeme moci zohlednit veškerou zahraniční diskuzi k tématu. ${ }^{8}$ Téma je zároveň natolik rozsáhlé, že ho můžeme pouze načrtnout $\mathrm{v}$ hlavních rysech. Nejprve popíšeme, jakým způsobem Ratzinger vztahuje tajemství církve na Krista, v druhé části

5 Srov. KASPER, Walter. Jesus der Christus. Leipzig: St. Benno-Verlag, 1981, s. 7-8.

6 Srov. GUARDINI, Romano. Die Kirche des Herrn. Meditation über Wesen und Auftrag der Kirche. Freiburg i. Br.: Herder, 1968, s. 73. Srov. vzpomínku významného exegety na Romana Guardiniho: LOHFINK, Gerhard. Ježišov posledný deň alebo Ako to bolo s Ježišovým umučeným. Bratislava: Serafín, 2008, s. 63. „Sowohl Guardini als auch Ratzinger setzen die Kirche in ihrer Wirklichkeit als geschichtliche Vermittlerin der Selbstoffenbarungen Gottes voraus (...) Denn ohne Kirche (...) könnte und hätte niemand den Zugang zur Person Jesu Christi. Diese Grundprämisse prägte Guardini sein Leben lang.“ HEIBEL, Franz-Xaver. Theologische Denker, s. 72.

7 V současné době probíhá diskuze především o papežově knize o Ježíši. Například v Německu vyšlo několik knih, které zahrnují různorodé příspěvky k tématu od velmi kritických - srov. např. HÄRING, Hermann (ed.). „Jesus von Nazareth“ in der wissenschaftlichen Diskussion. Berlin: Lit. Verlag, 2008 - až po poměrně pochvalné - srov. např. TÜCK, Jan-Heiner (ed.). Annäherungen an „Jesus von Nazareth“. Das Buch des Papstes in der Diskussion. Ostfildern: Matthias-Grünewald-Verlag, 2007.

8 V odkazech na sekundární literaturu k tématu se omezuji na německou oblast, ačkoliv různé studie nalezneme také v dalších jazycích, především v angličtině a francouzštině. Tento výběr je jistým ochuzením, na druhou stranu německá teologická recepce Ratzingerova díla je nejrozsáhlejší, nebot toto dílo reaguje především na německy psanou teologii. 
vyjádříme Ratzingerův přístup k christologii na základě církevní hermeneutiky. V závěru se pokusíme popsat některé praktické aplikace a shrneme a zhodnotíme naše zjištění.

\section{Církev jako Boží lid z Kristova Těla}

Kristus jako střed církve je bezesporu nejdůležitějším tématem Ratzingerovy ekleziologie. Významnou studii k tématu předložil ve své disertační práci Maximilian Heinrich Heim. Tento autor popsal Ratzingerovy základní ekleziologické myšlenky v souvislosti s koncilní konstitucí Lumen gentium. ${ }^{9}$ Kardinál Ratzinger sám několik měsíců před tím, než byl zvolen papežem, napsal k Heimově knize předmluvu, ve které vyzdvihuje autorovu analýzu Lumen gentium, jejímž teologickým středem je Kristus, nikoliv církev („Světlem národů“ je Kristus). Proto „zaměřit ekleziologii christologicky znamená chápat církev ze svátosti, znamená nakonec eucharistickou ekleziologii, znamená vřadit a podřídit lidské sociologické systémy a formy do základního řádu communio, který vyrůstá z eucharistie“. ${ }^{10}$ Tento citát nám ukazuje, že Ratzinger ve své christologicky zaměřené ekleziologii nechce chápat církev jen jako sociologickou veličinu, ale jako eucharistickou skutečnost. Pokusíme se nyní blíže představit Ratzingerovu eucharistickou ekleziologii v souvislosti s koncilním pojetím církve jako Božího lidu, jako Kristova Těla a jako communio.

\subsection{Koncilní pojem „Boží lid“ a jeho nesprávné pojetí}

Podle Heima „žádný jiný teologický základní pojem neměl po koncilu takový ohlas jako označení církve výrazem ,Boží lid“ “.11 Ratzinger vzpomíná, že koncilní otcové upřednostnili pojem „Boží lid“ před ostatními pojetími, především před „mystickým Tělem Kristovým“, ze tří důvodů. První důvod byl ekumenický, nebot' pojetí církve jako Božího lidu bylo blízké i protestantské teologii a protože pojem „Boží lid“ lépe řeší otázku členství církve, pro niž se idea „Kristova Těla“ zdála př́liš úzká. Druhý důvod byl pastorační. Pojetí církve jako „Kristova Těla“ př́liš identifikovalo církev s Kristem, a ztěžovalo tak vidět

9 Srov. HEIM, Maximilian Heinrich. Joseph Ratzinger - Kirchliche Existenz und existentielle Theologie. Ekklesiologische Grundlinien unter dem Anspruch von Lumen gentium. 2. přepracované vydání. Frankfurt am Main: Peter Lang, 2005.

10 Tamtéž, s. 7-8.

11 Tamtéž, s. 311. 
lidskou stránku církve, která vyžaduje reformu. Třetí aspekt je eschatologický: Církev jako putující Boží lid směřuje s nadějí k definitivnímu Božímu království. ${ }^{12}$

Ratzinger sleduje $\mathbf{v}$ pokoncilním vývoji dvě nesprávné tendence v chápání ideje „Božího lidu“: jednak redukování celé koncilní ekleziologie pouze na tento pojem a jednak transformaci původně biblického pojmu v pojem sociologický a politický:

„Lid“ se zdá být pojmem, který lze přepracovat sociologicko - politicky. Jestliže církev můžeme definovat pojmem „lid“, pak můžeme určit její podstatu a její právní uspořádání ze sociologických a politických hledisek. Takto se stal „Boží lid“ nositelem antihierarchické a antisakrální církevní ideje, ano, revoluční kategorií, která se hodí ke koncipování nové církve. ${ }^{13}$

Sociologizace církevního pojmu „Boží lid“, který se vzdaluje od biblického a koncilního pojetí, znamená především oloupení církve o její christologický střed a má samozřejmě dopad do konkrétního života církve. Projevuje se ve snaze politizovat církev, určovat ji podobně jako státní demokracii podle většinového principu apod. ${ }^{14}$ Církev se tak uzavírá pouze do sebe, do svých vlastních problémů. ${ }^{15}$

Jaká je příčina tohoto nemocného stavu církve? Je jím ztráta víry v Krista a v jeho božské působení, která vede ke snaze budovat církev pouze podle lidských cílů a měřítek. ${ }^{16}$ Podle Ratzingera je tedy církevní krize nikoliv problémem ekleziologickým, ale christologickým, spočívá v prosazení deistického pohledu na svět, ve kterém Bůh nepůsobí. ${ }^{17}$ Církev však není naše, ale Kristova, a proto není „žádný klub, žádná

12 Srov. RATZINGER, Joseph. Die Ekklesiologie des Zweiten Vatikanischen Konzils. In JRGS 8/1, s. 270-271.

13 Srov. tamtéž, s. 275.

14 K Ratzingerově analýze a kritice sociologického nesprávného chápání pojmu „Boží lid“ srov. HEIM, Maximilian Heinrich. Joseph Ratzinger, s. 354-367.

15 Heim cituje Ratzingera: „Eine Kirche, die allzu viel von sich selbst reden macht, redet nicht von dem, wovon sie reden soll.“ Tamtéž, s. 58.

16 Srov. RATZINGER, Joseph. Christus und Kirche. Aktuelle Probleme der Theologie. Konsequenzen für Katechese. In Ratzinger, Joseph. Ein neues Lied für den Herrn. Christusglaube und Liturgie in der Gegenwart. Freiburg i. Br.: Herder, 1995, s. 49-50.

17 „Deismus se prakticky prosadil ve všeobecném povědomí. Člověk si již více nedokáže představit Boha, který se stará o jednotlivého člověka a který jedná v dějinách (...) Proto nemůže samozřejmě být Syn Boží, který přišel do světa, aby nás vykoupil z hříchů.“ Tamtéž, s. 51-52. 
strana ani druh náboženského státu ve světském státě, ale Tělo - jeho Tělo, proto není církev vytvářena námi, ale jím samým."18

Ratzingerovu ostrou kritiku sociologizace ekleziologie a nutnost obnoveného pohledu na církev jako „Boží lid“ shrnuje Maximilian Heim:

Politické a filosofické vlivy osvícenství, tak jako marxismus, pragmatismus, subjektivismus, skepticismus, proporcionalismus a ne naposled relativismus se podle Ratzingerova úsudku v pokoncilním čase rozhodujícím způsobem podílely na tom, že se pojem „Boží lid“ transformoval především v Evropě a v Americe v pojem politický a sociologický. Z tohoto hlediska je zřejmé, proč k hlavnímu úkolu Ratzingerovy ekleziologie patř́ očistit pojem „Boží lid“ na základě jeho biblického původu a předávané tradice víry. ${ }^{19}$

\subsection{Koncilní pojem, „Boží lid“ $v$ Písmu a v tradici církve}

Ratzinger se již před koncilem zabýval pojmem „Boží lid“, tak jak je př́tomen v Písmu a chápán u otců, ve své disertační práci: Lid a dưm Boži v Augustinově učeni o církvi. Její autor sám vzpomíná na zajímavé zjištění: Augustin, stejně jako další otcové, zcela v duchu Nového zákona vztahoval pojem „Boží lid“ na Izrael. Církev je možné označit jako Boží lid pouze v „christologické transformaci“.20 Tedy žádný lid se nemůže stát „Božím“ sám, ale pouze skrze Boží povolání, které tento lid svolá, a vytvoří tak „shromážděni“, což je význam slova „Ecclesia“ - „církev“.21 Přechod od Izraele k novému Izraeli, od Božího

18 RATZINGER, Joseph. Církev jako společenství. Praha: Zvon, s. 109.

19 HEIM, Maximilian Heinrich. Joseph Ratzinger, s. 360.

20 Srov. RATZINGER, Joseph. Die Ekklesiologie des Zweiten Vatikanischen Konzils, s. 272-273. Podle Heima je základem christologického chápání pojmu „Boží lid“ u Ratzingera Augustinovo myšlení, jak to vyjadřuje formulace: „Das Volk Gottes hat seine eigentliche Wesensart darin, sakramentale Leib-Christi-Gemeinschaft, d. i. corpus Christi zu sein.“ HEIM, Maximilian Heinrich. Joseph Ratzinger, s. 310. K úzké souvislosti mezi christologicko-svátostným pojetím církve jako Božího lidu u Augustina a u Ratzingera srov. LAM, Joseph. Theologische Verwandtschaft. Augustinus von Hippo und Joseph Ratzinger - Papst Benedikt XVI. Würzburg: Echter Verlag, 2009, s. 49-83.

21 Srov. RATZINGER, Joseph. Die Ekklesiologie des Zweiten Vatikanischen Konzils, s. 272-273. Ratzinger upozorňuje na důležitou skutečnost, že se novozákonní církev neoznačuje jako Boží lid, ale jako „ekklésia“, což odpovídá starozákonnímu „qāhāl" - shromáždění Izraele. Toto shromáždění vytváří Bůh a jeho prototypem je shromáždění na Sinaji. V Novém zákoně je Kristus, živý Sinaj, který shromažd'uje nový Boží lid. Srov. RATZINGER, Joseph. Ursprung und Wesen der Kirche. In JRGS 8/1, s. 230-233. (Česky je článek obsažen v knize: RATZINGER, Joseph. Církev jako společenství. Praha: Zvon, 1994, s. 7-30.) 
lidu k novému Božímu lidu je možný pouze skrze dílo Ježíše Krista. Na rozdíl od některých církevních otců se však Ratzinger nedomnívá, že Kristus starý Izrael nahradil, ale spíše završil a učinil univerzálním. ${ }^{22}$ Podstatné však zůstává, že církev jako Boží lid je ve svém biblickém původu ${ }^{23}$ i v dalším patristickém podání úzce vázána na osobu Ježíše Krista:

Křestané nejsou jednoduše „Boží lid“. Empiricky vzato jsou „ne-lid“, jak každá sociologická analýza rychle může ukázat. Bůh nepatří nikomu, nikdo na něj nemá právo. „Ne-lid“ křestanů se může stát Božím lidem pouze včleněním do Krista, Syna Božího a syna Abrahámova. I když někdo mluví o „Božím lidu“, musí zůstat christologie středem učení o církvi. (...) Jsme Božím lidem pouze z ukřižovaného a zmrtvýchvstalého Těla Kristova. ${ }^{24}$

Ratzinger v mnoha dalších studiích, ve kterých shromažd'uje závěry exegetů, ukazuje, že novozákonní spisy jednoznačně spatřují původ církve v Ježíši Kristu. Zmiňme alespoň některé motivy: Ježíš svým hlásáním Božího království očištuje a shromažduje Boží lid - Izrael. ${ }^{25}$ Ježíš jako „praotec nového Izraele“ vytváří sbor dvanácti jako obnovu dvanácti kmenů Izraele. ${ }^{26}$ Tuto obnovu váže na svou osobu, protože je povolává, aby byli s ním (srov. Mk 3,14). ${ }^{27}$ Kristovi učedníci se stávají Ježíšovou „novou rodinou“, která přesahuje biologická a národní

22 „Ježíš nemusel Boží lid (,církev`) teprve zakládat. Ten už existoval; Ježíšovou úlohou bylo pouze tento lid prohloubeným vztahem k Bohu obnovit a otevřít celému světu.“ RATZINGER, Joseph. Hedét na Probodeného. Pokus o spirituálni kristologii. Brno: CDK, 1996, s. 21. Ačkoliv Ratzinger často používá pro popsání poměru křestanství k Izraeli výraz „nový“, zřetelně odmítá substituční teorii, tedy mínění, že smlouva s Izraelem byla nahrazena Novou smlouvou. Podle Ratzingera smlouva ve Starém a Novém zákoně je jediná smlouva naplněná v Kristově velikonočním tajemství. Srov. RATZINGER, Joseph. Der Neue Bund. Zur Theologie des Bundes im Neuen Testament. In JRGS 8/2, s. 1112-1115. Srov. MENKE, Karl-Heinz. „Starší bratři a sestry“. Teologické pojetí židovství u Josepha Ratzingera. MKR Communio 2009, č. 1, s. $69-71,77-79$.

23 „Der neutestamentliche Volk-Gottes-Begrif ist überhaupt nicht abseits der Christologie zu denken." RATZINGER, Joseph. Ursprung und Wesen der Kirche, s. 233.

24 RATZINGER, Joseph. Die Ekklesiologie des Zweiten Vatikanischen Konzils, s. $273-274$.

25 RATZINGER, Joseph. Ursprung und Wesen der Kirche, s. 226-227.

26 Srov. např. RATZINGER, Joseph. Das Geschick Jesu und die Kirche. In JRGS 8/1, s. 130-132.

27 RATZINGER, Joseph. Ursprung und Wesen der Kirche, s. 227. 
pouta, a dostává tak univerzální ráz. ${ }^{28}$ Univerzální charakter sboru dvanácti je naznačen také tím, že „dvanáct“ je symbol kosmické plnosti. ${ }^{29}$ Zvláště v poslední době hovoří současný papež o Ježíši jako „novém Mojžíši“, který „předává novou Tóru, takže z Izraele a národů může vzniknout nová rodina.“"30

Zcela zvláštní místo v Ježíšově shromažd'ování nového Božího lidu zaujímá podle Ratzingera Poslední večeře. Ježíšova Poslední večeře souvisí s Paschou Izraele. Při tomto svátku si starozákonní lid připomínal vysvobození z Egypta, a proto i své zrození jakožto Božího lidu. ${ }^{31}$ Svátek však nebyl pouze připomínkou, ale stálým zdrojem života a jednoty Izraele. Ježíšova slova poslední večeře však neodkazují jen na Paschu Izraele, ale také na smlouvu na Sinaji. Obě události mají pro Izrael konstitutivní význam. Ježíš jako Beránek obětovaný za spásu světa ustanovuje na základě nové smlouvy nové, univerzální společenství. Ježíšovo slavení poslední večeře má pro Ratzingera jasný smysl: „Tato večeře se ukazuje jako živý základ a stálý střed nového Izraele (...) tato nová večeře je poutem jednoty nového Božího lidu“32 Centrem Ježíšovy poslední večere je jeho Tělo, vydané za spásu světa, které je novým chrámem, novým kultem, sjednocuje křestany k nové a vyšší jednotě než kult a chrám starozákonní. ${ }^{33}$ Ratzinger takto shrnuje své zkoumání evangelijních zpráv o vzniku církve:

Ježíš vytvořil církev, to znamená nové viditelné společenství spásy. On ji pojímá jako nový Izrael, nový Boží lid, jenž má střed ve slavení Poslední večeře, ze kterého vznikl a ve kterém má svůj stálý životní střed. Nebo jinak řečeno: Nový Boží lid je lid, který vzešel z Kristova Těla. ${ }^{34}$

Ratzinger zdůrazňuje, že pojem „Boží lid“ nestojí v protikladu, ale je zcela podmíněn pojetím církve jako „Kristova Těla“. Toto pojetí, které

28 Téma církve jako nové univerzální Kristovy rodiny je znovu promýšleno v papežově knize o Ježíši v dialogu s židovským učencem Jakobem Neusnerem. Srov. RATZINGER, Joseph - BENEDIKT XVI. Ježǐš Nazaretský. Brno: Barrister \& Principal, 2007, s. $88-93$.

29 Srov. RATZINGER, Joseph. Das Geschick Jesu und die Kirche, s. 131.

30 RATZINGER, Joseph - BENEDIKT XVI. Ježiš Nazaretský, s. 80.

31 Srov. např. RATZINGER, Joseph. Vom Ursprung und Wesen der Kirche. In JRGS 8/1, s. 144.

32 Tamtéž, s. 147. Podobně RATZINGER, Joseph. Ursprung und Wesen der Kirche, s. 228-233.

33 Srov. RATZINGER, Joseph. Vom Ursprung und Wesen der Kirche, s. 147.

34 Tamtéž, s. 146. 
má základ v Ježíšově Poslední večeři, tedy v jeho velikonočním tajemství, je pak dále promýšleno u svatého Pavla a stalo se v dalších dějinách významným pojmem k popsání tajemství církve.

\subsection{Církev jako Tèlo Kristovo}

Ratzinger nás přivádí k důležitému zjištění, že označení „Tělo Kristovo" není plodem pavlovské teologie, ale vyjadřuje sebechápání církve od počátku. Pavlovo pojetí církve jako Kristova Těla, jak ho známe z 12. kapitoly Prvního listu Korintanům, však rovněž není pouhou metaforou. ${ }^{35}$ Vyjadřuje eucharistický charakter církve, jak je zřejmé z 1 Kor 10,16: „Není chléb, který lámeme, účastí na těle Kristově? Protože je jeden chléb, jsme my mnozí jedno.“ Proto, jak ř́ká Ratzinger, „vyjádření, že církev je ,Tělo Kristovo‘, znamená, že eucharistie, v níž nám Pán dává své Tělo a vytváří jedno Tělo z nás, je trvalé místo vznikání církve““36 Můžeme tedy shrnout, že Ratzinger v návaznosti na novozákonní pojetí církve ukazuje, že Kristus není pouze zakladatel církve, či její pouhý ideový učitel a vzor, ale že církev vzniká z eucharistického sjednocování Krista s křestany.

Eucharistické chápání pojmu „Kristovo Tělo“ bohužel upadlo v dějinách církve do určitého zapomenutí. Ratzinger se odvolává na bádání Henri de Lubaca a na jeho prrínosné dílo Corpus mysticum. ${ }^{37}$ Lubac objevil, že otcové považovali církev za pravé Tělo Pána (corpus verum) a eucharistii pak někdy označovali jako „corpus mysticum“, tedy jako svátostné tělo (mysticum tj. sacramentale). Až do 12. století bylo zřejmé, že církev vzniká z eucharistie a pouze prostřednictvím eucharistie je uchopitelná. Ve středověku se však slovo „mysticum“ přestalo používat pro eucharistii a začalo se používat pro církev, tím ztratilo význam sakramentální a získalo význam alegorický. Ze svátostného pojmu se stal pojem právní. Církev je chápana více institucionálně: Z Těla Kristova (corpus Christi) se stala korporace Kristova. ${ }^{38}$ Ratzinger tvrdí, že zde leží problém pozdější ekleziologie. Ve snaze překonat příliš institucionální chápání církve, které bylo ještě více zdůrazněné v protireformační ekleziologii, pokoušela se katolická romantika 19. a 20. století

\footnotetext{
35 K Ratzingerovu hodnocení pavlovského učení o těle Kristově srov. RATZINGER, Joseph. Ursprung und Wesen der Kirche, s. 233-237.

36 Tamtéž, s. 235-236.

37 Srov. RATZINGER, Joseph. Der Kirchenbegriff und die Frage nach der Gliedschaft in der Kirche. In JRGS 8/1, s. 299-301.

38 Srov. tamtéž, s. 300.
} 
chápat slovo „mysticum“ jako odvozené z mystiky, tedy z niternosti. V myšlence církve jako Kristova Těla tak stojí dvě protichůdná pojetí: institučně-právní a romanticko-mystické. ${ }^{9}$ Encyklika Mystici corporis (1943), ač znamená průlom v katolické ekleziologii, tento rozpor nemohla uspokojivě vyřešit, nová cesta začíná až konstitucí Lumen gentium, která se vrací k biblickým a patristickým kořenům.

Podle Ratzingera je možné překonat umělou dualitu mezi vnějším a vnitřním v církvi jen skrze původní biblicko-patristické pojetí „církve jako Božího lidu, který se při eucharistickém slavení stává Tělem Kristovým“.40 Pouze na tomto základu je možné řešit konkrétní ekleziologické otázky, jako je vztah mezi církví viditelnou a neviditelnou, instituční a charismatickou, univerzální a místní, ${ }^{41}$ otázku členství v církvi, úřadu v církvi, ekumenismu aj.

\subsection{Církev jako communio}

Ratzinger překonává nesprávné pochopení koncilní myšlenky „Božího lidu“v nalezení jejího christologického středu, tedy v její úzké souvislosti s pojmem „Kristovo Tělo“, který má eucharistický význam, jak ukázal Henri de Lubac. Pouze takto je podle něj možné správně pochopit přínos koncilu, nebot' „izolovaný pojem ,Boží lid‘ se stává jen karikaturou koncilní ekleziologie.“42

Především Henri de Lubac ozřejmil ve svém výjimečném, obsáhle poučném díle, že slovo „corpus mysticum“ původně označovalo Nejsvětější eucharistii, a že je jak pro Pavla, tak pro církevní otce myšlenka církve jako Kristova Těla neoddělitelně spjata s myšlenkou eucharistie, ve které je Pán př́ítomen a ve které nám dává za pokrm své Tělo. Takto vznikla eucharistická

39 Srov. tamtéž, s. 301. Podobně RATZINGER, Joseph. Leib Christi. In JRGS8/1, s. 286-289.

40 RATZINGER, Joseph. Der Kirchenbegriff und die Frage nach der Gliedschaft in der Kirche, s. 300.

41 K otázce vztahu mezi univerzální a místní církví je třeba zmínit významnou kontroversi mezi kardinálem Walterem Kasperem a kardinálem Ratzingerem, která probíhala na přelomu tisíciletí. Z Ratzingerovy communio-ekleziologie vyplývá, že univerzální církev chronologicky a ontologicky předchází místní církvi. Priorita univerzální církve vůči místní církvi znamená ekleziální prioritu jednoty před mnohostí. Naproti tomu Kasper ve své communio-eklezilogii spatřuje stejný počátek, a proto vzájemnou rovnost mezi univerzální a místní církví, mezi ekleziální jednotou a mnohostí. K tomuto zajímavému sporu srov. MENKE, Karl-Heinz. Der Leitgedanke Joseph Ratzingers. Die Verschränkung von vertikaler und horizontaler Inkarnation. Paderborn: Ferdinand Schöning, 2008, s. 27-46.

42 Srov. RATZINGER, Joseph. Die Kirche als Heilssakrament. In JRGS 8/1, s. 257. 
ekleziologie, která se také nazývá communio-ekleziologie. Tato communio-ekleziologie se stala vlastním jádrem učení Druhého Vatikána o církvi, je tím novým a zároveň zcela původním, co nám chtěl koncil předat. ${ }^{43}$

Pro Ratzingera je myšlenka „communio“ jádrem a syntézou nejen koncilní, ale též jeho vlastní ekleziologie. ${ }^{44}$ Podle našeho autora se však pojetí církve jako communio - společenství, které se v posledních desetiletích stává po Božím lidu novým heslem, často chápe izolovaně a banálně. ${ }^{45}$ Nemá-li toto učení upadnout do čistě horizontálního pojetí pouhé vzájemné sounáležitosti a vzájemné dohody, musí být zřejmé, že „pojem communio je nejdříve zakotven v Nejsvětější svátosti eucharistie“.46

V této souvislosti je zajímavé, že koncil jako vlastní označení církve spíše než slovo „communio“ vyzdvihl pojem „svátost“ (mystérium): „Církev je v Kristu jakoby svátost neboli znamení a nástroj vnitřního spojení s Bohem a jednoty celého lidstva“ (LG 1). Podle Ratzingera má toto pojetí za následek vyloučení individualistického chápání svátosti

43 RATZINGER, Joseph. Die Ekklesiologie des Zweiten Vatikanischen Konzils, s. 262.

44 Samotný pojem „communio“ neměl během koncilu centrální místo, důležitým teologickým pojmem se stal až během koncilní recepce, a to především po mimořádné biskupské synodě v roce 1985, která pojem „communio“ vyzdvihla jako centrální a základní ideu koncilní ekleziologie. Srov. HEIM, Maximilian Heinrich. Joseph Ratzinger, s. 270. Srov. RATZINGER, Joseph. Eucharistie - Communio - Solidarität: Christus gegenwärtig und wirksam im Sakrament. In Ratzinger Joseph. Unterwegs zu Jesus Christus. Augsburg: Sankt Ulrich Verlag, 2003, s. 115-116.

45 Srov. tamtéž, s. 113-116. Zajímavé je také Ratzingerovo rozlišení concilium a communio. Podle Hanse Künga je možné chápat církev jako trvalý koncil, podle Ratzingera církev může dělat koncil, ale není koncil, není ze své podstaty konciliární, ale communiální. Tento Ratzingerův pohled na církev ilustruje to, že na počátku sedmdesátých let minulého století odešel z pokoncilního teologického časopisu Concilium a spolu s Hansem Urs von Balthasarem založil časopis Communio. Srov. tamtéž, 114-115. Ratzinger se ve svém pojetí koncilu vědomě odlišuje od teologů, kteří koncil nevnímají jako závazné měřítko teologické debaty, ale jako východisko, které má být překonáno, jako „počátek dalšího počátku“ (Karl Rahner). Naproti tomu Ratzinger podle analýzy Heima „nepojímá koncil jako,počátek počátku“ ve smyslu hnutí, které se vzdaluje od svého východiska, ale jako stálý vztažný bod. HEIM, Maximilian Heinrich. Joseph Ratzinger, s. 195. V tomto ohledu je důležité Ratzingerovo vlastní svědectví: „V roce 1973 nastal zásadní obrat. Tehdy se objevil názor, že texty II. vatikánského koncilu nemohou již být styčným bodem katolické teologie (...) koncil může být pouze výchozím bodem. Avšak v oněch letech jsem se již určitou dobu od vedení i od spolupracovníků Concilia distancoval. Vždy jsem se snažil být věrný II. Vaticanu, tomuto dnešku církve, bez touhy po nenávratných včerejšcích a bez netrpělivého usilování o zítřek, který nám přece nepatří.“ RATZINGER, Joseph. O viŕe dnes. Rozhovor s Vittoriem Messorim, Olomouc: Matice cyrilometodějská, 1998, s. 17-30. 10-11.

46 Tamtéž, s. 117. 
jako zprostředkování milosti jednotlivci. Svátost je totiž výkonem církve, a milost svátosti člověka sjednocuje s Bohem, a tím s druhými lidmi, tedy s církví. V pojetí církve coby svátosti odpovídá koncil na touhu lidstva po jednotě. Tato jednota je však možná pouze skrze Kristovu lásku, kterou církev ve svátosti zpřítomňuje a která osvobozuje člověka z osamocenosti a uvádí do společenství. ${ }^{47}$ Myšlenka „jednoty“ je tedy vlastním obsahem pojmu „svátost“: „Sjednocení s Bohem je význam milosti, avšak toto sjednocení má za následek jednotu mezi lidmi navzájem.“48 Jednota, po které lidstvo touží, je možná pouze skrze sjednocení s Bohem, člověk toho však nemůže dosáhnout sám, avšak Bůh se s člověkem identifikuje a uskutečňuje communio v eucharistii:

Teprve nyní jsme se dostali k nejvnitřnějšímu jádru církevního pojmu, a tím k nejhlubšímu významu toho, co se míní, když se mluví o svátosti jednoty. Církev je communio, ona je komunikováním Boha s lidmi v Kristu, a tak mezi lidmi navzájem, a proto je svátostí, znamením a nástrojem spásy. Církev je slavení eucharistie, eucharistie je církev, oboje nestojí vedle sebe, ale v sobě, odtud vyzařuje všechno ostatní. Eucharistie je svátost Krista, a protože je církev eucharistií, proto je sacramentum - svátostí, které jsou ostatní svátosti přiřazeny. ${ }^{49}$

Je zřejmé, že Ratzinger vidí podstatu učení o církvi jako svátosti v eucharistii, která je „znamením a nástrojem vnitřního spojení s Bohem a jednoty celého lidstva.“ Právě toto spojení a jednotu mezi Bohem a lidmi navzájem vyjadřuje pojem „communio“. Jak mu však rozumět? Podle Ratzingerovy analýzy vyplývá, že vztah mezi Bohem a člověkem ve Starém zákoně není popsán slovem „communio“, nýbrž slovem „smlouva“, nebot přes jistou blízkost zůstává transcendence Stvořitele nepřekročitelná. Teprve Nový zákon je communio, v osobě a skrze osobu Ježíše Krista. ${ }^{50}$ Sjednocení přirozeností v hypostazi Slova znamená uskutečnění communio Boha a člověka. Jednota Boha

47 Srov. RATZINGER, Joseph. Die Kirche als Heilssakrament, s. 251-252. V souvislosti s koncilním chápáním církve jako svátosti zmiňuje Ratzinger opět myšlení Henri de Lubaca. Srov. tamtéž, s. 249-251.

Tamtéž, 252.

49 Tamtéž, s. 255-256.

50 Srov. RATZINGER, Joseph. Kommunion - Kommunität - Sendung. Über den Zusammenhang von Eucharistie, Gemeinschaft (Gemeinde) und Sendung in der Kirche. In JRGS 8/1, s. 319. (Česky je článek obsažen v knize: RATZINGER, Joseph. Hledèt na Probodeného. Pokus o spirituální kristologii. Brno: CDK, 1996, s. 55-67.) 
s člověkem, která se uskutečňuje v osobě Syna, se podle Ratzingera komunikuje ve velikonočním tajemství. Člověk má na této jednotě podíl v eucharistii, vytváří se tak communio církve. ${ }^{51}$

Pro popsání myšlenky eucharistického sjednocení Krista s člověkem používá Ratzinger pavlovsko-augustinovské přirovnání jídla, při kterém pokrm není vstřebán v člověka, ale kdy se člověk asimiluje v eucharistický pokrm, v Krista. ${ }^{52}$ Nebo se také odvolává na Pavlovo přirovnání duchovně-tělesného sjednocení manželů, kteří jsou jedno tělo a jedna duše, což se v eucharistii děje mezi Kristem ženichem a nevěstou církví. ${ }^{53}$ Tato vyjádření popisují vlastní charakter církve, prolomení uzavřeného já v Kristovo ty: Vzájemné proniknutí subjektů „já“ a „ty“, vytváří a umožňuje subjekt „my“ církve. Tento proces není jen christologický, ale též pneumatologický, děje se v Duchu svatém. Kristovo vzkř́íšené tělo je schopné sdílet se věřícím v eucharistii a sjednocovat je se sebou i mezi sebou navzájem, protože je „Duchem oživujícím“ (srov. 1 Kor 15,45). ${ }^{54}$

Ratzingerovo eucharistické pojetí církve má pochopitelně mnoho dalších důsledků, jako je zásadní význam liturgie pro život církve, úzká vazba mezi communio a solidaritou, mezi communio a missio. My se však vrátíme k řešení problematiky, kterou jsme zmínili na začátku, totiž k otázce identifikace křestana s církví.

\subsection{Od soukromého ,já" $k$ církevnímu ,já}

Problematiku identifikace křestana s církví je možné podle Ratzingera řešit na základě pojmu „communio“. Nejprve je však třeba říci, že podle našeho autora je v církevní krizi zjevná krize víry v Boha. Heslo „Ježíš ano, církev ne“ vyvolává otázku: Jaký Ježíš? Heslo by mělo spíše znít: „Ježíš ano, Kristus ne“ nebo „Ježíš ano, Boží Syn ne“. V podtextu je

51 „Vtělení Syna vytváři communio mezi Bohem a člověkem, a otvírá tak možnost nového communio mezi lidmi navzájem. Toto communio mezi Bohem a člověkem, které se uskutečňuje v osobě Ježíše Krista, se stává komunikabilní ve velikonočním tajemství, tj. ve smrti a zmrtvýchvstání Páně. Eucharistie je naší účastí na velikonočním tajemství a konstituuje tak církev, Tělo Kristovo. Odtud pramení spásná nezbytnost eucharistie. Nezbytnost eucharistie je identická s nezbytností církve a naopak.“ Tamtéž s. 326-327.

52 Srov. RATZINGER, Joseph. Ursprung und Wesen der Kirche, s. 235.

53 Srov. tamtéž, s. 236.

54 Srov. RATZINGER, Joseph. Eucharistie - Communio - Solidarität, s. 128-129. K Ratzingerovu pneumatologickému chápání pojmu „Kristovo Tělo“ a k úzké vazbě mezi christologií a pneumatologií s ohledem na ekleziologii srov. např. RATZINGER, Joseph. Kirche als Tempel des Heiligen Geistes. In JRGS 8/1, s. 334-344. 
tedy problém christologický, nikoliv ekleziologický. Prosazení deistického pohledu na svět vede k neschopnosti vidět v Ježíši Boha, proto se vytvářejí konstrukce necírkevního, pouze lidského „historického Ježíše“.55 Ratzinger souhlasí s Johannem Baptistem Metzem, že krize víry v církev je krizí víry v osobního Boha, heslo dneška by tak mohlo být: „Náboženství ano, Bůh ne“"56 Pokud však Ježíš není Bủh, tak církev je pouhou lidskou organizací, sociologickou veličinou mezi dalšími. Je-li však Ježíš communio Boha a člověka, pak je také církev communio a otázka identifikace má teologický základ.

Teologickým základem úvah o identifikaci je Bůh, který se ztotožňuje s člověkem a s jeho lidským osudem v Ježíši Kristu. Člověk se sám s Bohem nemůže identifikovat, nebot́ mu „chybí prostředky, které by překonaly diferenci mezi konečným a Nekonečným“. ${ }^{57}$ Proto identifikace člověka s Bohem je „možná pouze v identifikaci s Kristem, protože Bůh se v něm sám s člověkem identifikoval“ “58 Právě v tomto našem identifikování se s Kristem, který se nejprve s námi identifikoval, vzniká církev ve smyslu Pavlovy formulace: „Vy všichni jste jedním v Kristu Ježíši“ (srov. Gal 3,28). To je také význam pavlovské myšlenky Kristova Těla. ${ }^{59}$ Ratzinger své úvahy uzavírá:

Tím je předně vyloučena christologie a ekleziologie v zúženém pojetí „solus Christus“, nebot právě to je vlastní Kristu, že si vystavěl a staví Tělo. Identifikace s ním je stále identifikace se všemi, kteří mu náležejí, a pouze takto je ztotožnění s Kristem poznatelné a opravdové. Tím ovšem také vylučujeme možnost něčeho takového jako je „ecclesia separata“. Našemu „ano“ vůči církvi rozumíme jako sjednocení s Kristem, který je sjednocen se svou církví. ${ }^{60}$

To ovšem neznamená, že by u Ratzingera byla ekleziologie pohlcena christologií. Communio mezi Kristem a jeho církví není naprostá totožnost mezi oběma subjekty, v tom smyslu je viditelná církev vždy na cestě očištění, obrácení, tedy reformy. ${ }^{61}$ Communio, které má svátostný ráz, však vylučuje možnost přijmout Krista bez církve.

55 Srov. RATZINGER, Joseph. Christus und Kirche, s. 47.

56 Srov. RATZINGER, Joseph. Die Ekklesiologie der Konstitution Lumen gentium. In JRGS 8/1, s. 574-576.

57 RATZINGER, Joseph. Identifikation mit der Kirche. In JRGS 8/1, s. 187.

58 Tamtéž, s. 188.

59 Srov. tamtéž, s. 189

60 Tamtéž, s. 190.

61 Srov. RATZINGER, Joseph. Ursprung und Wesen der Kirche, s. 237. 
Takto se dostáváme k dalšímu důležitému kroku v Ratzingerově výkladu. Církev není pouze doplněk, nebo následek identifikování jednotlivce s Kristem, ale je jakožto communio jeho předpokladem. Víra a vztah ke Kristu nemůže být pouhou soukromou, individuální záležitostí. Náš autor tuto skutečnost dokresluje na svátosti křtu. ${ }^{62}$ Při křtu katechumen vyznává svou osobní víru v Krista v credu, které vyjadřuje víru církve. „Já“ jednotlivce tak vstupuje a je neseno v „já“ církve směrem ke Kristovu „Ty“. Křestanská existence je tak vždy církevní existence: Člověk nalézá své pravé „já“ tím že opouští své osobní uzavřené „já“ a otvírá se vyššímu subjektu Kristovy církve:

„Já“ formule creda je kolektivní „já“, „já“ věřící církve, kterému „já“ jednotlivce náleží, nakolik věří. „Já“ creda otvírá tedy přechod od soukromého „jä“ k církevnímu „jä“. Proto credo strukturálně předpokládá „já“ církve: Pouze v communio církve se vyjadřuje toto „já“. Jednota vyznávajícího subjektu nutně koresponduje a vychází z vyznávaného „objektu“, z vyznávaného protějšku, který takto přestává být pouhý protějškem. ${ }^{63}$

Tento hutný Ratzingerův text, znovu inspirovaný H. de Lubacem, vyjadřuje vzájemné shodování a pronikání subjektů církve a křestana s objektem víry, kterým je nakonec subjekt Krista. Můžeme shrnout, že pro Ratzingera má křestanská víra, teologie a život církevní charakter a že víra v Krista předpokládá církev. ${ }^{64}$

\section{K zjevení patří přijímající subjekt církve}

Sledujeme-li vývoj Ratzingerovy christologie od Úvodu do krestáanstvi až po papežovu knihu o Ježíši, objevíme, že jejím trvalým a základním tématem je překonání novověkého oddělování „historického Ježíše“ od „Krista víry“.65 Je zřejmé, že náš autor na jedné straně odmítá

62 Srov. RATZINGER, Joseph. Theologische Prinzipienlehre. Bausteine zur Fundamentaltheologie. München: Erich Wewel Verlag, 1982, s. 36-38.

63 Srov. tamtéž, s. 23. „Věřit je ze své podstaty pořád věřit spolu s celou církví. ,Věřm‘ ve vyznání víry nevyjadřuje nějaké soukromé ,jác, ale společné ,já‘ církve. Víra je možná v míře mého sjednocení s tímto společným ,jác, které moje vlastní ,jác neruší, nýbrž rozšiřuje a teprve tak přivádí k sobě samému.“ RATZINGER, Joseph. Vom Geistlichen Grund und vom kirchlichen Ort der Theologie. In RATZINGER, Joseph. Wesen und Auftrag der Theologie. Versuche zu neuer Ortbestimmung im Disput der Gegenwart. Einsiedeln: Johannes Verlag, s. 82.

64 Srov. tamtéž, s. 39-60. Srov. HEIM, Maximilian Heinrich. Joseph Ratzinger, s. 144-150.

65 Vývoj Ratzingerovy christologie jsem se pokusil popsat ve své diplomové práci „Christologie v díle Josepha Ratzingera“. Výsledky práce jsem shrnul a rozvinul ve svém 
rezignaci na historii v kérygmatické teologii R. Bultmanna, na druhé straně však také kritizuje konstrukty „historického Ježíše“, vypracovávané bez hermeneutiky víry. Jak ukazuje papežova kniha o Ježíši, v poslední době je to především dominantní historicko-kritická exegeze, která pokud nezohledňuje víru církve, „nechává slovo v minulosti (...) a nemůže je přenést do př́ítomnosti.“66

Papežův pokus představit „historického Ježíše“ jako „Ježíše evangelijního“ tak, jak je př́tomen v Písmu svatém, jejímž živým subjektem je církev, ${ }^{67}$ vyvolal množství různých reakcí. Abychom však tomuto metodickému př́stupu papežovy christologie lépe porozuměli, musíme nejprve pojednat o jeho koncepci zjevení. Jestliže jsme v předchozí kapitole ukázali souvislost mezi Ratzingerovým ekleziologickými myšlením a koncilní konstitucí Lumen gentium, je třeba, abychom se nyní zmínili o druhém koncilním dokumentu, kterým je konstituce o Božím zjevení Dei Verbum. Srovnání Ratzingerovy teologie zjevení a Dei Verbum na způsob Heimova důkladného ekleziologického porovnání s Lumen gentium, pokud je nám známo, doposud nikdo nepředložil. Existuje však množství drobnějších studií, týkajících se Ratzingerovy christologické metody. Z hlediska biblické teologie jsou to především články Thomase Södinga, ${ }^{68} \mathrm{z}$ fundamentálně teologické perspektivy pak práce Hansjürgena Verweyena ${ }^{69}$ a Rudolfa Voderholzera. ${ }^{70} \mathrm{~V}$ následujícím oddíle pojednáme o Ratzingerově chápání zjevení v kontextu koncilní teologie Dei Verbum a následně popíšeme jeho aplikaci v papežově metodě církevně-teologického výkladu Písma svatého.

článku: FRÝVALDSKÝ, Pavel. Christologie v díle Josepha Ratzingera - Benedikta XVI. Studia Theologica 2010, roč. 12, č. 3, s. 43-62.

66 RATZINGER, Joseph - BENEDIKT XVI. Ježís Nazaretský, s. 8, 9.

67 Tamtéž, s. 9. K analýze církevní víry jako horizontu papežovy christologie srov. FRANZ, Albert. Der Jesus des Papstes. Anmerkungen zu Joseph Ratzinger - Benedikt XVI.: Jesus von Nazareth. In LEHMANN, Karl (ed.). „Jesus von Nazareth“ kontrovers: Rückfragen an Joseph Ratzinger. Berlin: Lit Verlag, 2007, s. 52-58.

68 Srov. např. SÖDING, Thomas. Die Lebendigkeit des Wortes Gottes. Das Verständnis der Offenbarung bei Joseph Ratzinger. In MEIER-HAMIDI, Frank - SCHUMACHER, Ferdinand (ed.). Der Theologe Joseph Ratzinger. Freiburg i. Br.: Herder, 2007, s. 12-56. Srov. např. VERWEYEN, Hansjürgen. Ein unbekannter Ratzinger. Die Habilitationsschrift von 1955 als Schlüssel zu seiner Theologie. Verlag Friedrich Pustet: Regensburg, 2010.

70 Srov. VODERHOLZER, Rudolf. „Schriftauslegung im Widerstreit“ - Joseph Ratzinger und die Exegeze. In MÜLLER, Gerhard Ludwig (ed.). Der Glaube ist einfach. Aspekte der Theologie Papst Benedikts XVI. Regensburg: Verlag Friedrich Pustet, 2007, s. 54-84. Srov. VODERHOLZER, Rudolf. Die biblische Hermeneutik Joseph Ratzingers. Die Münchener Theologische Zeitschrift 2005, č. 56, s. 400-414. 


\subsection{Zjevení u svatého Bonaventury}

Jestliže Ratzinger čerpal poznatky pro určení christologického středu pojmu „Boží lid“ ze svého bádání o ekleziologii u sv. Augustina, pak pro popsaní vztahu zjevení a církve byla zásadní jeho habilitační práce o zjevení u sv. Bonaventury. V této práci náš teolog objevil, že Bonaventura nechápe zjevení v novověkém smyslu jako obsah pravd k věření, ale jako Boží čin, který vyžaduje přijímající věřící subjekt:

Ke „zjeveni““ patří vnitřní, věřící přijetí řečeného, poznání „pro me“, poznání, že se výpověd” týká mě. O skutečném „zjevení může být pouze tehdy řeč, kde se nezůstává pouze u vnějšího slova, nýbrž kde se děje skutečný vnitřní kontakt s Bohem, kde dochází k vnitřnímu osvícení osloveného člověka Bohem. ${ }^{71}$

Jak Ratzinger analyzuje, zjevení je u Bonaventury dialogická událost mezi člověkem a Bohem. Není pouze objektivní skutečností zaznamenanou v Písmu, jak bylo v novověku obvykle chápáno. Je-li zjevení dialogickou událostí, znamená to, že nelze ztotožnit Písmo a zjevení, protože zjevení předchází Písmu a v Písmu je zachyceno, ale není s Písmem identické. Dialogický charakter zjevení rovněž implikuje, že k pojmu zjevení patří přijímající subjekt někoho, kdo zjevení s vírou přijímá a na ně odpovídá. Tímto přijímajícím subjektem zjevení je církev. Z toho vyplývá, že ačkoliv je zjevení historickou událostí, nelze ho fixovat pouze do minulosti, ale $\mathrm{v}$ přijímajícím subjektu církve je stálou přítomností, je trvalým dialogem Boha a člověka. ${ }^{72}$ Ratzinger své zjištění shrnuje ve svých vzpomínkách:

„Zjevení“ je vždy pojmem činu. Toto slovo označuje čin, v němž se Bůh ukazuje, ne zobjektivizovaný výsledek tohoto činu. A protože je tomu tak, náleží k pojmu „zjeveni“ vždy také přijímající subjekt. Kde nikdo „zjeveni““ nevnímá, tam k žádnému zjevení nedošlo, nebot̉ se nestalo nic zjevného.

71 RATZINGER, Joseph. Offenbarungsverständnis und Geschichtstheologie Bonaventuras. In RATZINGER, Joseph. Gesammelte Schriften. Offenbarungsverständnis und Geschichtstheologie Bonaventuras. Habilitationsschrift und Bonaventura-Studien. MÜLLER, Gerhard Ludwig (ed.). 2. sv., (JRGS2). Freiburg i. Br.: Herder, 2009, s. 86-87. Srov. RATZINGER, Joseph. Ein Versuch zur Frage des Traditionsbegriffs. In RATZINGER, Joseph. Wort Gottes. Schrift - Tradition - Amt. HÜNERMANN, Peter - SÖDING, Thomas (ed.). Freiburg i. Br.: Herder, 2005, s. 47-48. Srov. VERWEYEN, Hansjürgen. Ein unbekannter Ratzinger, s. 44-47; VODERHOLZER, Rudolf. Die biblische Hermeneutik, s. 402-403. 
Ke zjevení náleží už z tohoto samotného pojmu někdo, kdo si ho uvědomí. Úsudky, které jsem získal při četbě Bonaventury, pro mě byly později, př̀i koncilní disputaci o zjevení, Písmu a tradici, velmi důležité. Nebot pokud je tomu tak, potom zjevení předcházelo Písmu a zachycuje se v něm, ale není s ním prostě identické. To potom znamená, že zjevení je vždy větší než to, co je pouze sepsáno. A to zase znamená, že nemůže existovat „sola scriptura“, že k Písmu patří chápající subjekt církve, čímž je dán podstatný smysl tradice. ${ }^{73}$

Dříve, než zaměříme svou pozornost na koncilní disputaci o zjevení, je třeba říci, že Ratzingerova habilitační práce narazila na odmítnutí koreferenta profesora Schmause, který podle Ratzingerových slov „neviděl v tezích věrný obraz Bonaventurova myšlení, nýbrž nebezpečný modernismus, který by musel vyústit v subjektivizaci pojmu zjevení،"74 Spis tak mohl být vydán teprve nedávno, lze ho však chápat jako určitý klíč k Ratzingerovu chápání zjevní, Písma a tradice.

\subsection{Koncilní debata o zjevení}

Mladý teolog Ratzinger, jako poradce kolínského kardinála Fringse, sehrál aktivní roli především při vzniku konstituce Dei Verbum. ${ }^{75}$ Ratzinger předně patřil ke kritikům prvního schématu konstituce „De fontibus revelationis“ (Prameny zjevení), které pojímalo Písmo a tradici jako dva prameny zjevení. Takové pojetí znamená „zúžení pojmu zjevení“. Písmo a tradice totiž nejsou dva zdroje zjevení, spíše naopak zjevení je jediným pramenem („fons essendi“), ze kterého Písmo a tradice vychází. Písmo a tradici lze označit toliko za prameny poznání („fontes cognoscendi“) zjevení. ${ }^{76}$ Ratzingerovo bonaventurovské pojetí zjevení, které předchází a transcenduje Písmo a tradici, odpovídalo názoru většiny koncilních otců a $\mathrm{v}$ dalším průběhu přispělo k formulování konstituce Dei Verbum. 77 Tato konstituce zjevení pojímá christologicky

73 RATZINGER, Joseph. Můj život, s. 72-73.

74 Tamtéž, s. 73. Verweyen skutečně ukazuje na souvislost mezi Ratzingerovými závěry a „modernistou“ Mauricem Blondelem. Srov. VERWEYEN, Hansjürgen. Ein unbekannter Ratzinger, s. 33.

75 Podle Johna Allena je Dei Verbum koncilní dokument, na který měl Ratzinger největší osobní vliv. Srov. ALLEN, John. Kardinal Ratzinger. Düsseldorf: Patmos Verlag, 2002, s. 27.

76 Srov. VERWEYEN, Hansjürgen. Ein unbekannter Ratzinger, s. 31-32. Srov. VODERHOLZER, Rudolf. Die biblische Hermeneutik, s. 400-401.

77 Srov. VERWEYEN, Hansjürgen. Ein unbekannter Ratzinger, s. 32. 
a předřazuje zjevení Písmu a tradici, které nejsou chápany jako zdroje zjevení, ale jako způsoby jeho předávání (DV 7-10). ${ }^{78}$

Daleko problematičtější byla následná diskuze o vztahu mezi Písmem a tradicí. Velký ohlas na koncilu měla teze Josepha Ruperta Geiselmanna, podle kterého Písmo obsahuje veškeré pravdy víry v celistvosti, tradice tedy nemůže přinést nic jiného než to, co je již obsaženo v Písmu. ${ }^{79} \mathrm{~V}$ Geislemannově pojetí „materiální úplnosti Písma“ je však znovu skryto nesprávné ztotožňování a zaměňování Písma a zjevení. Pro Ratzingera však „zjevení znamená celé mluvení a jednání Boha k člověku, je skutečností, jejíž je Písmo svědkem, ale není s ním totožné. Zjevení překračuje Písmo ve stejné míře, jako skutečnost převyšuje svědectví o ní.“80 Písmo tedy nemůže být „materiálně úplné“, to může být pouze zjevení. Pro Ratzingera je zjevením Kristus sám. Dostatečná je pouze skutečnost Krista, nikoliv jednoduše Písma. Zjevení proto vyžaduje víru a církev, ve které je přijímáno:

Přijetí zjevení, ve kterém se přivlastňuje Kristova skutečnost, se označuje v biblické řeči jako „víra“. Můžeme tak zřetelněji pochopit, proč v Novém zákoně je víra chápána jako Kristovo přebývání. Přijímáme-li jako fakt, že pro Písmo je přítomností zjevení přítomnost Krista, vyplývá z toho další krok. Kristovu přítomnost nacházíme v Písmu v dvojí podobě. Ukazuje se na jedné straně, jak jsme již slyšeli, jako identická s vírou (...) Je však ukryta také v pavlovském výroku o „Kristově Těle“, který chce vyjádřit, že společenství věřících - církev - představuje Kristovo přebývání v tomto světě, do kterého Kristus shromažduje lidi a ve kterém jim dává účast na své tajemné prrítomnosti. (...) Z toho vyplývá, že př́ítomnost zjevení podstatně souvisí se skutečnostmi „víry“ a „církve“. 81

Ratzingerovo pojetí zjevení můžeme popsat následovně: Zjevením není Písmo, ale Kristus živě přítomný ve své církvi, která ho vírou přijímá. Proto Písmo bez víry církve zůstává mrtvou literou minulosti, což je úskalí jednostranné historicko-kritické exegeze. Mnoho dalších

\footnotetext{
78 Srov. VODERHOLZER, Rudolf. Die biblische Hermeneutik, s. 400. Podle Voderholzera je kvůli koncilnímu christologickému chápání zjevení lepší psát slovo „Verbum“ v názvu konstituce s velkým písmenem.

79 Srov. RATZINGER, Joseph. Můj život, s. 88-89.

80 RATZINGER, Joseph. Ein Versuch zur Frage des Traditionsbegriffs. In RATZINGER, Joseph. Wort Gottes. Schrift - Tradition - Amt, s. 47.

81 Tamtéž, s. 53.
} 
otázek, které se zde otevírají, jako je vzájemný vztah Písma, tradice a učitelského úřadu jsou zodpověditelné pouze na tomto základu. My se zaměříme na důsledky, které z Ratzingerova chápání zjevení vyplývají pro exegezi.

\subsection{Syntéza historicko-kritické a církevnè-teologické exegeze}

Ratzingerův postoj k historicko-kritické metodě výkladu evangelií je značně diferencovaný. Ratzinger sám se poprvé setkal s historicko-kritickou metodou během svých teologických studií v Mnichově prostřednictvím svého učitele Fridricha Wilhelma Maiera. Ratzinger vzpomíná, že Maierova liberální historická metoda nebyla uzavřena dogmatu, tedy víře církve. ${ }^{82}$ Právě díky Maierovi získal Ratzinger pozitivní vztah k historicko-kritické metodě a přesvědčení, že ji lze uvést do souladu s církevně předávanou vírou. ${ }^{83}$ Pozdější Ratzingerův stále více kritický postoj k současné historické exegezi je reakcí na historické rekonstrukce, vypracované bez hermeneutiky víry. ${ }^{84}$ Joseph Ratzinger se tak na jedné straně odlišuje od teologů, kteří ve svém díle nezohledňují historickou exegezi, jako byl Karl Rahner, nebo Paul Tillich, a na druhé straně i od těch teologů, kteří nekriticky intence historicko-kritické exegeze přijímají a zpochybňují církevní dogma, jako je to patrné např. v díle Hanse Künga. ${ }^{85}$

Důvod, proč Ratzinger zdůrazňuje nutnost historické metody, vychází nakonec z tajemství vtělení věčného Slova, ve kterém je založen lidsko-dějinný charakter Božího slova. Rezignaci na historii v teologii proto považuje za jistý druh doketismu. ${ }^{86} \mathrm{Z}$ tohoto důvodu

82 Srov. RATZINGER, Joseph. Můj život, s. 50-52.

83 Srov. VERWEYEN, Hansjürgen. Joseph Ratzinger - Benedikt XVI. Die Entwicklung seines Denkens. Darmstadt: Primus Verlag, 2007, s. 84.

84 K Ratzingerově přístupu k moderní exegezi srov. především: RATZINGER, Joseph. Schriftauslegung im Widerstreit. Zur Frage nach Grundlangen und Weg der Exegese heute. In RATZINGER. Wort Gottes. Schrift - Tradition - Amt, s. 83-116. Srov. pozoruhodnou studii k tématu VODERHOLZER, Rudolf. „Schriftauslegung im Widerstreit" - Joseph Ratzinger und die Exegeze. In MÜLLER, Gerhard Ludwig (ed.), 2007, s. 54-84.

85 Srov. RATZINGER, Joseph. Schriftauslegung, s. 85; VODERHOLZER, Rudolf. Schriftauslegung, s. 58-59. K metodologickému sporu Ratzingera s Küngem srov. Ratzinger, Joseph. Wer verantwortet die Aussagen der Theologie? Zur Methodenfrage. In BALTHASAR, Hans Urs von (ed.). Diskussion über Hans Küngs „Christ sein“. Mainz: Matthias Grünewald Verlag, 1976, s. 7-18.

86 „Pro biblickou víru je zásadní, že se vztahuje ke skutečnému historickému dění (...) Factum historicum pro ni není vyměnitelná symbolická šifra, nýbrž konstitutivní základ: et incarnatus est - těmito slovy vyznáváme skutečný vstup Boha do reálných dějin. Jestliže tyto dějiny odsuneme, křesṫanská víra jako taková se rozplyne a promě- 
Ratzinger odmítá Bultmannovu nedůvěru k historicitě novozákonních událostí a redukci historie na filosofii. ${ }^{87}$ Tento trvalý zájem o historii vedl vždy současného papeže k dialogu, třebaže často kritickému, s významnými představiteli historické exegeze ${ }^{88}$ at' už katolickými (Rudolf Schnackenburg, Joachim Gnilka), nebo protestantskými (Joachim Jeremias).

Kritická připomínka k historické metodě se týká, již zmíněného, vztahu mezi exegezí a vírou církve. Ratzinger se odvolává na koncilní dokument Dei Verbum, který mluví nejen o významu historické metody, ale zdůrazňuje rovněž „teologický charakter exegeze“. K základnímu předpokladu teologické četby Bible patří chápat Písmo jako celek, to nám umožňuje používat „,analogie fidei“, tedy rozumět jednotlivým textům z celku Bible. To, že Bible tvoří celek, vychází nakonec z toho, že její původ je třeba hledat v církvi, jejíž víra je „vlastním hermeneutickým klíčem“. ${ }^{89}$ Číst Písmo historicko-kritickou metodou bez hermeneutiky církevní víry má za následek rozpad Bible do nesourodých celků a vytváření „historických konstruktů“, které nakonec biblický text degradují pouze na dokument minulosti. ${ }^{90}$ Pro Ratzingera proto zůstává podstatné vytvořit „syntézu mezi historickou metodou a (církevně) teologickou hermeneutikou“.91

Nyní přistoupíme k Ratzingerovu návrhu syntézy mezi historickou metodou a církevní vírou. Východiska Ratzingerova přístupu velmi dobře analyzuje německý teolog Rudolf Voderholzer. Voderholzer uvádí jména dvou biblistů, kteří hlouběji objasnili vyznání církve jako předpoklad vzniku Písma. Jsou jimi Ratzingerem velmi cenění Heinrich Schlier a Franz Mußner. Schlier přesvědčivě dokazuje, že christologické dogma není dodatečné shrnutí nedogmatických evangelních vyprávění, ale spíše naopak církevní vyznání víry v čase i věcně předchází Písmu. ${ }^{92}$ Schlierův poznatek, že dogma předchází Písmu a ne naopak, dále prohlubuje Mußner, podle kterého nebyla evangelia sepsána jako

ní se v jinou formu religiozity. Patří-li tedy dějiny, faktično v tomto smyslu podstatně ke křestanské víře, pak se tato musí vystavit historické metodě - víra sama si to žádá.“ RATZINGER, Joseph - BENEDIKT XVI. Ježíš Nazaretský, s. 7-8.

Srov. RATZINGER, Joseph. Shriftauslegung, s. 94-105.

88 Srov. VODERHOLZER, Rudolf. Schriftauslegung, s. 59.

89 Tamtéž, s. 88.

90 Srov. tamtéž, s. 90; RATZINGER, Joseph - BENEDIKT XVI. Ježí̌s Nazaretský, s. 8-9.

91 RATZINGER, Joseph. Schriftauslegung, s. 89.

92 Srov. VODERHOLZER, Rudolf. Schriftauslegung, s. 63-65. 
korektiv nezapsaného hlásání církve, ale jako zdůvodnění a podepření jeho správnosti. ${ }^{93}$

Jestliže Bible vděčí za svůj vznik církvi, doporučuje Ratzinger vedle dominantní historické metody, takzvanou „kanonickou exegezi“, která nahlíží Písmo jako celek z hlediska jejího kánonu, který vytvořila církev.94

Současný papež tedy neodmítá historická bádání jako taková. Sám jejich výsledky využívá. Usiluje ovšem o jejich začlenění do církevně předávané víry..$^{95}$ Některým badatelům se může tento přístup jevit nedostatečným, nebot' využívá výsledky historické exegeze selektivně, pouze nakolik jsou v souladu a podporují církevní dogma. ${ }^{96}$ To však podle Ratzingera odpovídá charakteru Písma.

Můžeme uzavřít v návaznosti na Ratzingerovo pojetí zjevení, že syntéza mezi historicko-kritickou a církevně-teologickou exegezí vychází z chápání zjevení, které je historickou skutečností, ale které nepatří pouze do minulosti, nýbrž v přijímajícím subjektu církve je stálou přítomností. Písmo, které není zjevením, ale svědectvím o přijetí zjevení v církvi, se proto nemůže stát pouhým historickým dokumentem. Proto také pro zkoumání Bible nestačí nástroje historické vědy, nebot́ exegeze vyžaduje hermeneutiku církevní víry.

\section{Shrnutí a závěr}

Nyní se pokusíme shrnout a zhodnotit výsledky našeho zkoumání. Vztah Krista a církve má u Ratzingera dvojí podobu, který shrnuje výrok: „Bez církve mizí Kristus v minulosti; bez Krista, Zmrtvýchvstalého, Syna Božího, se stává církev pouhou organizací bez vnitřní jednoty “97 Ukázali jsme, že pokud není církev pevně zakotvena v Kristově tajemství, hrozí jí ztráta identity, kterou nelze nahradit sociologickými konstrukty. Církev v Kristu je vždy církev jako svátost, církev jako eucharistie. Svátosti, především eucharistie, tak nemohou být pouze

93 Srov. tamtéž, s. 66-67.

94 RATZINGER, Joseph - BENEDIKT XVI. Ježíš Nazaretský, s. 9-11.

95 Tamtéž, s. 9.

96 Srov. např. EBNER, Martin. Jeder Ausleger hat seine blinden Flecken. In SÖDING, Thomas (ed.). Das Jesus-Buch des Papstes: Die Antwort der Neutestamentler. Freiburg i. Br.: Herder 2007, s. 33-38. „Wenn ich die methodischen Vorüberlegungen Benedikts richtig verstehe, ist für ihn die historische Forschung mit all ihren methodischen Regulierungen der Schutzwall, der die Glaubensicht davor bewahrt, theologischen Symbolen zu erliegen.“ Tamtéž, s. 34.

97 RATZINGER, Joseph. Dogma und Verkündigung. München - Freiburg: Erich Wewel Verlag, 1973, s. 48. 
nedůležitými projevy církve, ale jsou pro ni konstitutivní. Proto je také pochopitelný Ratzingerův důraz na správné chápání a slavení liturgie i jeho provokativní teze, že „krize církve je krizí liturgie.“98 Z druhé strany jsme také pozorovali, že nejenom Kristus je zdrojem života církve, ale také církev je předpokladem pro poznání skutečného Krista. Pouze v církvi je možné se setkat s živým Kristem, bez církve se Kristus ztrácí v množství historických hypotéz.

Zároveň jsme objevili úzkou souvislost mezi Ratzingerovým myšlením a koncilní teologií dokumentů Lumen gentium a Dei Verbum. Teologie současného papeže je do velké míry důležitou interpretací koncilu, brání nás před mnohdy zdomácnělým avšak zjednodušeně horizontálním chápáním pojmů „Boží lid“ a „společenství (communio)“, anebo před jednostrannou kanonizací historicko-kritického výkladu Bible.

Ratzingerova teologie má bezesporu velký praktický dopad do života církve. Připomíná nám, že to nejsme v první řadě my, tedy naše plány a aktivity, kdo buduje církev, ale že je to živý Kristus, který si skrze eucharistii „staví své Tělo“. To pro církev znamená primát modlitby a důraz na úctu k eucharistii. Dále nám papež ukazuje, že ke skutečnému poznání Krista nestačí pouhá soukromá snaha, ale že je to církev, která umožňuje skutečné osobní setkání s Kristem.

Tyto úvahy nás také přivádějí k některým možným kritickým otázkám. Nejprve vzniká námitka ekumenická. Neuzavírá se nám eucharistickou ekleziologií ekumenický dialog s církvemi vzešlými z reformace? Tato ožehavá otázka nebyla předmětem našeho zkoumání a jistě bychom na ni nějakou odpověd' u Ratzingera nalezli. Je však zajímavé, že náš autor nevěnuje ve své ekleziologii tolik pozornost svátosti křtu, která s eucharistií souvisí. Možná by právě teologie křtu lépe umožňovala ekumenický dialog o církvi coby svátosti.

Jeden reformační teolog vyslovil také námitku, že v Ratzingerově christologicko-ekleziologické syntéze ztrácí Kristus vůči své církvi exkluzivní postavení. Z hlediska evangelické ekleziologie však může být Ježíš základem církve pouze pro svou odlišnost a jedinečnost. ${ }^{99}$ Ratzingerův teologický důraz je sice jiný, avšak nemůžeme říci, že by

98 Srov. RATZINGER, Joseph. Ke struktuře slavení liturgie. Mezinárodní katolická revue Communio 2009, roč. 13, č. 3, s. 360-370.

99 Srov. RINGLEBEN, Joachim. Lutherische Anfrage an Joseph Ratzingers Darstellung der Passion Jesu. In SÖDING, Thomas (ed.). Tod und Auferstehung Jesu. Theologische Antworten auf das Buch des Papstes. Freiburg i. Br.: Herder 2011, s. 136-137. 
jeho snaha zdůraznit úzký vztah mezi Kristem a církví vedla k ztotožnění obou skutečností. Jak jsme ukázali, jednotu mezi Kristem a církví lze popsat pojmem „communio“, který vyjadřuje jednotu lásky, tedy takovou jednotu, která nestírá odlišnost. 100

Další námitka může být kulturní. Žijeme ve společnosti, která se v mnohém církvi odcizila a nerozumí jí, je-li úkolem církve hlásat Krista, nemá to činit necírkevně tedy civilně? Nemá Krista přiblížit způsobem, který je blízký sekularizované společnosti? Jeden autor vyslovil názor, že papežova kniha o Ježíši je pro člověka mimo církev nesrozumitelná. ${ }^{101}$ Ratzingerova odpověd' by jistě nešla ve směru možné odpovědi, kterou by dal jiný německý teolog Klaus Berger. Ten by řekl, že cizota církve je cizotou Krista, ale právě ve své cizotě je Kristus zajímavý. ${ }^{102}$ Pro Ratzingera není jiný Ježíš než Kristus víry, pouze toho má církev hlásat. Avšak Ježíš je také „Logos“ je odpovědí na nejhlubší, existenciální otázky člověka, který hledá smysluplný „logický“ život. Církevní Ježíš proto nemusí být cizí. Ukáže-li se jako odpověd' na otázky rozumu, může být blízký. ${ }^{103}$ Dotýkáme se úzkého sepjetí víry a rozumu, které umožňuje dialog církve se světem.

Na závěr bych se vrátil k úvodnímu svědectví Eugena Bisera, podle kterého teolog Ratzinger překonal církevní krizi tím, že tajemství církve konsekventně vztahoval na Krista. Je jasné, že tato christologická krize církve stále není zažehnána, současný papež však nabízí ve své teologii účinný lék v úzkém sepětí Krista a jeho církve. Zdá se, že církevní krize bude překonána, až současný křestan objeví odpověd' na svoje existenciální otázky ne pouze ve vlastní činnosti, ale ve víře v Ježíše Krista; ve víře, která ho zároveň spojuje s církví. Jedině takto může objevit svou lidskou existenci nejen jako křestanskou, ale také jako církevní.

100 Kromě pojmu „communio“ můžeme zmínit původně trinitární pojem „perichoreze“, který vyjadřuje vzájemné pronikání a přebývání jednotlivých božských osob Trojice v sobě navzájem, jednotu lásky, která ovšem nestírá jejich identitu. Trinitární perichorze zakládá možnost perichoreze v christologii, tedy přebývání Syna v lidství, které je s ním hypostaticky sjednoceno. Srov. POSPÍŠIL, Ctirad Václav. Jako v nebi tak i na zemi. Náčrt trinitární teologie. Kostelní Vydří - Praha: Karmelitánské nakladatelství - Krystal OP 2007, 397-398. Analogicky můžeme vztah mezi Kristem a církví můžeme označit za perichoretický, tedy jako vzájemně se prostupující jednotu, která neruší odlišnost.

101 Srov. FRANZ, Albert. Der Jesus des Papstes, s. 54-55.

102 Srov. papežem vyzdviženou knihu: BERGER, Klaus. Jesus. München: Pattloch Verlag, 2007, s. 417.

103 Srov. např RATZINGER, Joseph. Glaube, Philosophie und Theologie. In RATZINGER, Joseph. Wesen und Auftrag der Theologie, s. 11-26. 


\begin{abstract}
PAVEL FRÝVALDSKÝ

"Without church Christ disappears in the past, without Christ church becomes a mere organisation." The relationship of Christ and church in the work of Joseph Ratzinger - Benedict XVI
\end{abstract}

The relationship of Christ and church is an important topic in the work of Joseph Ratzinger - Pope Benedict XVI. This article presents a summary of Ratzinger's theological approach in a double respect: first, it shows how the current Pope relates the mystery of church to Christ, then it expresses Ratzinger's approach to Christology on the ground of church hermeneutics. The close connection between Christ and church, which is rethought by the author in the context of up-to-date Christological crisis of church life and in consequence of the 2nd Vatican Council (Lumen gentium, Dei Verbum), is conveyed by the Ratzinger's notion of church as God's people, which rises from Christ's body, and by his explanation of revelation, which is necessarily tied to the accepting subject of the church. Therefore church without Christ is dead and Christ without church incognoscible.

\title{
Key words
}

Joseph Ratzinger - Benedict XVI, Christology, Ecclesiology, Revelation, Eucharist 